\title{
FINANCIAL SOUNDNESS INDICATORS
}

\author{
DANIELA ZAPODEANU, MIHAIL-IOAN COCIUBA *
}

\begin{abstract}
Following the financial-economic crisis the financial systems worldwide have been subjected to enormous pressure, which called into question the need for financial system stability in general and in particular the one of the banking system. We overview the most important indicators in financial stability and we analyze the evolution of the main indicators of financial health for the Romanian banking system as a whole and for two banks, respectively BRD and Transylvania Bank. We find that banks with foreign shareholders tend to be more riskier then domestic banks, also an important role in banks stability is the presence of an institutional investor.
\end{abstract}

KEYWORDS: economic crises; economic stability; financial stability; financial soundness indicators; banking system

JEL CLASIFICATION: $G 01, G 21$

\section{FINANCIAL STABILITY. FUNDAMENTAL NOTIONS.}

Financial stability can be a difficult concept to explain, because there is no widely accepted definition [Oosterloo and De Hann, 2003], for some authors financial stability is defined in relation to what financial stability is not: "...we define financial stability as the absence of instability ... the situation in which economic performance is not undermined (weak) by the price fluctuations of financial assets or because financial institutions are unable to meet contractual obligations ... [Crockett, 1997] or "... financial instability refers to situations (conditions) in which financial markets affect or threaten to affect economic performance ..." [Chant, 2003]. We believe that a proper definition of financial stability is not about what isn't (in this case financial instability) but rather what is financial stability, as "... We have financial stability where there is: a) monetary stability, b) the level of employment is close to the natural level of the economy, c) there is confidence in financial institutions and the functioning of financial

\footnotetext{
* Assoc. Prof., Ph.D., University of Oradea,Romania, danizapodeanu@yahoo.com

Ph.D. Student, University of Oradea, Romania, cociuba@gmail.com
} 
markets in the economy, d) there aren't relative motion of asset prices, real or financial in the economy that would undermine a) or b).

Viewed from a positive perspective we define the term by following the definition given by Schinas [Schinas and others, 2004], "...(the financial stability is that situation) in which the financial system is capable to: (a) allocate resources efficiently between its activities and over time, (2) assess and manage financial risk, and (3) to absorb shocks. A stable financial system is then one that improves the economic performance and accumulation of wealth (taking into account the first two parts), while it is also possible to prevent effects caused by the impact of disruptive disorders (third appearance).”

The National Bank defines financial stability [Financial Stability Report, 2006]"... a financial system, regardless of size or complexity, is stable when it has the capacity to facilitate economic performance and to correct any imbalances that may occur as a result of adverse shocks " (this is also the definition of financial stability given by the IMF). Another definition [Cerna et al., 2008] is: "Financial stability means the characteristic of the financial system, which has the ability to absorb financial imbalances that may arise as a result of endogenous or exogenous events, of relevant size and unanticipated, also accomplishing the specific performance".

We will retain the definition of financial stability given by the European Central Bank: "... (it is) difficult to define, the concept of financial stability should be seen not only in terms of avoiding financial crises. Financial stability, also has a positive dimension. Is the situation where the financial system is able to perform well all its normal tasks and it is expected to do that also in the near future. From this viewpoint, financial system stability requires that the main components of the system financial institutions, markets and infrastructure - to be able together to absorb the side effects. It requires that the financial system to achieve efficiency in reallocation of financial resources from savers to investors, that financial risk is assessed and measured properly and that risks are managed effectively. Financial stability has also an important prospective dimension: inefficiencies in the allocation of capital or shortcomings in risk assessment may, by laying the foundations for vulnerabilities, compromise the future of financial stability and therefore the economic stability. Three steps are necessary to produce a comprehensive view of financial system stability. The first involves the formation of an individual assessment and then the sound of collective institutions, markets and infrastructure that make up the financial system. The second involves identifying the main sources of risk and vulnerability that could pose challenges for the future stability of the financial system. The third and last step is an assessment of the financial system's capacity to cope with the crisis, whether these risks are materialized."

It can be noticed that having provided positive definitions for the concept of financial stability means to actually understands what is financial stability: the natural and normal state of functioning of the financial markets, which are able to resist endogenous and exogenous shocks, financial stability is the normal condition of the economy and financial instability is the exception to this condition. Until recently financial stability hasn't been in the focus of national and supranational institutions, but due to the mutations occurring in the global economy (especially the phenomenon 
of globalization of markets) led to an increased risk in the international spread of crises which led to the desire to minimize the risks of contagion and to increase the strength of the international financial system. An important question which may be raised is related to the natural state of the financial system, is it one of stability or instability? We believe that the economic system in general and especially the financial one are in a natural state of stability, reliability; what is sought by national and international bodies is a preventive treatment to prevent any slippage or if the slippage appear to be short and with as few adverse effects (eg. inflation, unemployment, economic decline, etc..) to the economy and society.

The Financial Stability Board which is the continuer of the Financial Stability Forum was established in 1999 by ministers and central bank governors of the G7, aimed at creating new structures to increase cooperation between national and international supervisors on the one hand and financial international institutions for enhancing the level of stability in the financial international system. FSB seeks to: analysis the vulnerabilities affecting the financial system, identifying and promoting measures to reduce them; promote coordination and exchange of information between authorities responsible for maintaining financial stability; monitoring and advising the development of markets and their implications for policy adjustment; counseling and monitoring to implement the best practices in achieving the standards of regulation; implementation of joint actions, creating international bodies able to respond in a timely, coordinated, focused on overcoming obstacles; setting guidelines for development of supervisory institutions; to manage cross-border crisis management plans, especially on systemically important firms; to cooperate with the IMF to carry out simulations on early warning systems.

Many of the recommendations issued by the FSF have been implemented in our country under the supervision of the NBR, in 2006 was signed "The Protocol for cooperation to promote stability in the overall financial system and his components " signed by the following authorities of regulation and supervision: NBR, NSC, CSA CSPP. Since July 31, 2007 The National Board for Stability was established with the duties "to promote continuous and effective exchange of information between authorities responsible for regulation and supervision of different sectors of the financial system and the Minister of Finance and the preventions of financial crises in financial institutions, financial groups and financial markets". As an EU member, Romania takes part in agreements existing in the European Union, as from 1 August 2007 NBR signed the declaration of accession to the Agreement on basic principles for cooperation in crisis management (signed by EU countries in 2003) and the Agreement on Cooperation between the authorities responsible for monitoring the payment systems and banking supervisors (signed by EU countries in 2001). From June 1, 2008 enter into force the Agreement on Cooperation between financial supervisory authorities, central banks and finance ministries of EU cross-border financial stability. This agreement replaced the agreement of cooperation between banking supervisors, central banks and finance ministries of EU countries in financial crisis, which was signed in 2005. The new agreement includes: common principles for cross-border financial crisis management, a common analytical framework for assessing the systemic implications of potential crises, to ensure common terminology applicable to 
cross-border financial crisis by all relevant authorities and the prerequisites for making timely assessments are necessary to facilitate the adoption of decisions in crisis situations, a practical guide for crisis management, reflecting a common understanding of the steps and procedures for crisis management. Romanian National Bank issues annually since 2006 " The report on financial stability", the document that aims at following: Economic and international finance. Economic and financial situation internationally is one of the exogenous factors that may threaten local financial stability through diverse factors; Financial market and its risks; Financial market infrastructure; Financial market institutions.

The last three are endogenous factors of financial stability, tracking all these elements is necessary because a skidding to a certain level of any item mentioned may threaten stability in the financial and banking system. The key indicators for analyzing financial stability are [Cerna et al, 2008]: The Financial soundness indicator; Stress testing, which represents testing the response of the financial system to speculative pressure factors; Early warning systems; Other methods of analysis and assessment of financial stability.

In this paper we analyze the set of financial soundness indicators proposed by the IMF on the local banking system and the banks: Bank of Romania and Banca Transilvania.

\section{LOCAL ECONOMIC SITUATION AND THE FINANCIAL SOUNDNESS INDICATORS}

Unlike developed countries which were affected by the crisis since the end of 2007 our country began to feel the first effects of the crisis only in september-october of 2008. If in Romania the crisis began thorough an unfold in credit loss rate, because almost $90 \%$ of banking assets are held by banks with foreign capital and branches of foreign banks the crisis started to feel from the fall of 2008 when foreign European banks began to suffer from lack of market confidence. After that followed a period of devaluation of the RON and the lowering of imports, exports and even trade deficit, trade deficit remained at low levels compared to previous periods because of strong contractions that existed at the level of domestic demand, an encouraging sign is the higher pace in which exports have recovered this is what makes the current account deficit to be reduced to levels consist of a single figure. Foreign exchange market was among the first to have been affected by financial crisis, many foreign investors on the national currency, Ron, considering it overvalued. The exchange rate risen sharply which affected the ability of many borrowers who had debt denominated in foreign currencies, the central bank intervened actively, since 2008, seeking to maintain a stable course of the exchange rate. After signing the IMF contract, the loan obtained was clearly stipulated that a part of it will just be used by the central bank to maintain the stability of RON. The level of imports and exports continued to decline during 2009, with a return in early 2010 however, growth forecast 2010 was amended to decrease up to $1-2 \%$ of GDP. Given the difficult international climate, and the needs for short-term borrowing, the Romanian government has managed to conclude a financing agreement for 20 billion euros. The perception on the international markets 
of our country's has improved as a result of signing the Agreement with the IMF, but remains one of the highest in the Central and Southeast region of Europe, this because of factors related to the central government's budgetary policy.

Another risk factor in the banking and financial stability is the component of the Romanian banking system, an banking system dominated by mostly private and foreign capital. In Romania, Romanian banking system is dominated in an proportion of $88.1 \%$ by foreign capital (to the share of bank assets), an proportion of $6.6 \%$ by credit institutions with a Romanian majority private capital and $5.3 \%$ by credit institution own by the state.

From an total of 42 credit institutions only BT, Cheque Bank, Eximbank Bank Carpathian and Libra Bank have domestic capital. Which raised various issues relating to the return of capital to foreign banks, the cuts in credit lines from the parent bank and the risks faced by Romanian subsidiaries if the parent bank collapse. Due to the huge exposure to which Austrian, Greek, Iberian, Dutch banks had on emerging markets, they have gone through periods in which the appeal to loans from the countries where they were based, which had put additional pressure on subsidiaries and led to cessation of credit lines from parent banks.

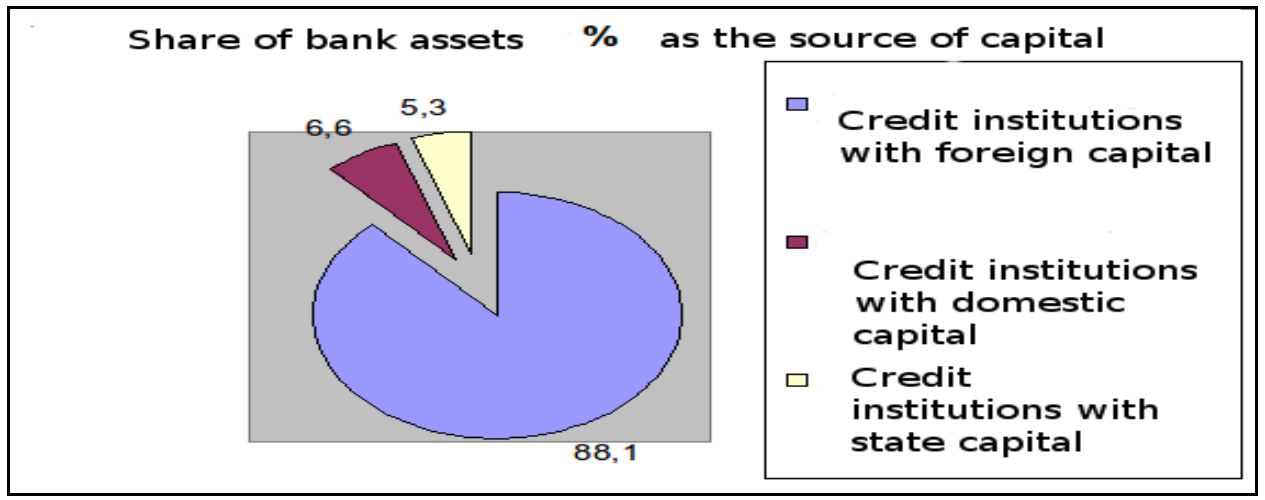

Source: www.bnro.ro, 2009, own calculations

Figure 1. The share of bank assets according to source capital

The financial crisis has turned into an economic crisis affecting the GDP of emerging countries from EU, the falls in GDP mainly affected the Baltic states (the levels of contraction being $10-20 \%$ of GDP ), the IMF forecasts for coming years show an improvement, resumption of economic growth and continuing the convergence of the new EU members. IMF played a key role in stabilizing this region, almost all countries signing agreements obtaining the financial resources necessary to finance budget deficits, the IMF plays at global and local level the role of an international creditor and also a stabilization role.

To analyze the financial stability within the national banking system we will analyze some of the indicators proposed by the IMF, namely the Financial soundness Indicators. NBR presents the financial soundness indicators annually in the Financial Stability Report (Table 1), we can note that in 2008-2009 period the main indicators of financial health of the Romanian banking system have getting worse, the biggest 
depression is observed at the level of overdue loans . Because before the financial crisis the most banks had a policy of massive lending to increase market share, banks are now affected by the financial crisis. Note that especially foreign ownership of banks, which wanted a rapid increase in assets and market share now face the biggest problems. The examined banks cover over $40 \%$ of the entire banking system, while the first five banks account for over half of total banking assets.

Table 1. Indicators of credit institutions

\begin{tabular}{|l|l|c|c|c|c|c|c|c|c|}
\hline & & U.M. & $\mathbf{1 2 / 0 7}$ & $\mathbf{0 3 / 0 8}$ & $\mathbf{0 6 / 0 8}$ & $\mathbf{0 9 / 0 8}$ & $\mathbf{1 2 / 0 8}$ & $\mathbf{0 3 / 0 9}$ & $\mathbf{0 6 / 0 9}$ \\
\hline 1 & $\begin{array}{l}\text { No. of credit } \\
\text { institutions }\end{array}$ & no. & 42 & 42 & 41 & 42 & 43 & 43 & 43 \\
\hline 2 & $\begin{array}{l}\text { branches of foreign } \\
\text { banks }\end{array}$ & no. & 10 & 10 & 9 & 9 & 10 & 11 & 11 \\
\hline 3 & Assets & Mil.lei & 251425.8 & 264448.3 & 279812.8 & 297200.4 & 314441.5 & 332342.3 & 328891.8 \\
\hline 4 & $\begin{array}{l}\text { Private owned assets/ } \\
\text { total assets }\end{array}$ & $\%$ & 94.6 & 94.6 & 94.6 & 94.7 & 94.8 & 93.7 & 93.2 \\
\hline 5 & $\begin{array}{l}\text { Foreign owned assets/ } \\
\text { total assets }\end{array}$ & $\%$ & 87.7 & 87.6 & 87.7 & 87.9 & 88.2 & 86.6 & 85.9 \\
\hline 6 & Solvency ratio > 8\% & $\%$ & 13.78 & 12.99 & 12.78 & 11.85 & 13.76 & 13.16 & 13.51 \\
\hline 7 & Leverage effect & $\%$ & 7.32 & 7.2 & 7.3 & 7.1 & 8.13 & 6.81 & 6.92 \\
\hline 8 & $\begin{array}{l}\text { Overdue and doubtful } \\
\text { loans/total loans }\end{array}$ & $\%$ & 0.22 & 0.21 & 0.3 & 0.24 & 0.32 & 0.66 & 1.03 \\
\hline 9 & $\begin{array}{l}\text { Overdue and doubtful } \\
\text { loans/total assets }\end{array}$ & $\%$ & 0.17 & 0.19 & 0.25 & 0.22 & 0.29 & 0.52 & 0.75 \\
\hline 10 & ROA & $\%$ & - & 1.51 & 1.44 & 1.77 & 1.56 & -0.25 & 0.05 \\
\hline 11 & ROE & $\%$ & - & 16.45 & 15.82 & 19.41 & 17.04 & -2.9 & 0.64 \\
\hline
\end{tabular}

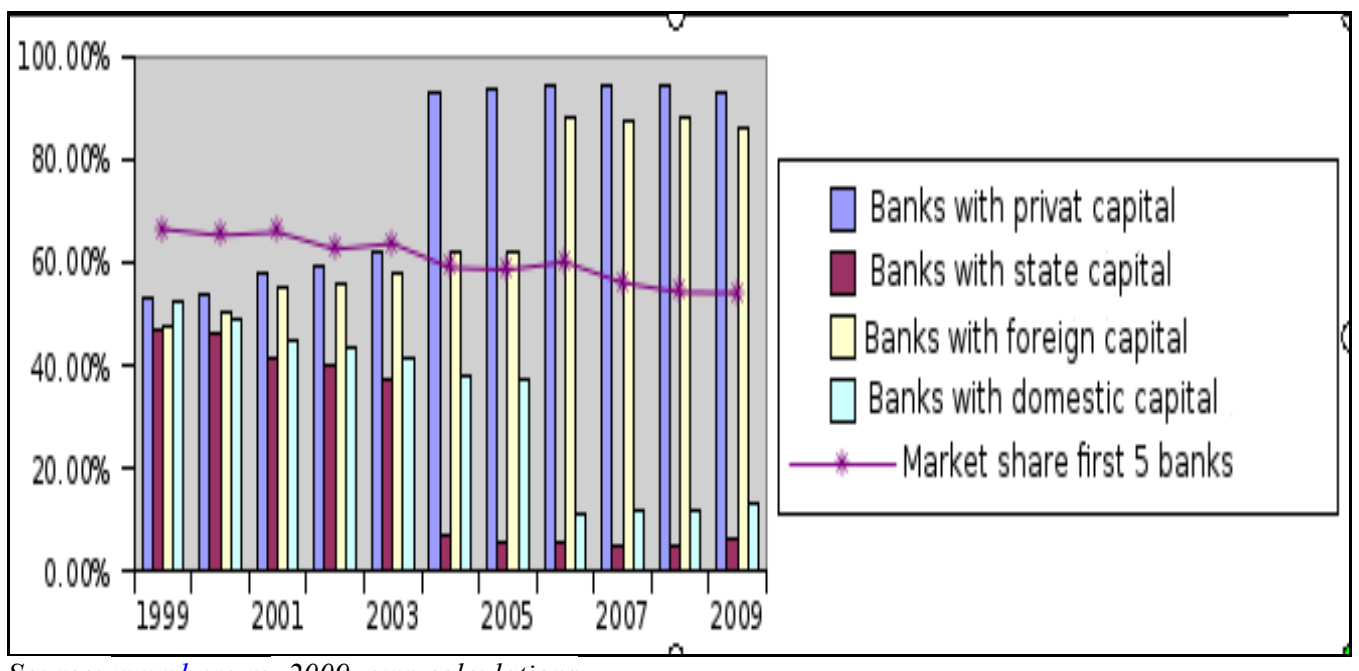

Source: www.bnro.ro, 2009, own calculations

Figure 2. Share of balance sheet assets according to the source and structure of capital 
Table 2. Financial soundness indicators

\begin{tabular}{|c|c|}
\hline \multicolumn{2}{|l|}{ Core set } \\
\hline \multicolumn{2}{|l|}{ Deposit-taking institutions } \\
\hline \multirow[t]{2}{*}{ Capital adequacy } & Regulatory capital to risk-weighted assets \\
\hline & Regulatory Tier I capital to risk-weighted assets \\
\hline \multirow[t]{3}{*}{ Asset quality } & Nonperforming loans to total gross loans \\
\hline & Nonperforming loans net of provisions to capital \\
\hline & Sectoral distribution of loans to total loans \\
\hline \multirow[t]{4}{*}{ Earnings and profitablity } & Return on assets \\
\hline & Return on equity \\
\hline & Interest margin to gross income \\
\hline & Noninterest expenses to gross income \\
\hline \multirow[t]{2}{*}{ Liquidity } & Liquid assets to total assets (liquid asset ratio) \\
\hline & Liquid assets to short-term liabilities \\
\hline Sensitivity to market risk & Net open position in foreign exchange to capital \\
\hline \multicolumn{2}{|l|}{ Encouraged Set } \\
\hline \multirow[t]{12}{*}{ Deposit-taking institutions } & Capital to assets \\
\hline & Large exposures to capital \\
\hline & Geographical distribution of loans to total loans \\
\hline & Gross asset positions in financial derivatives to capital \\
\hline & Trading income to total income \\
\hline & Personnel expenses to noninterest expenses \\
\hline & Spread between reference lending and deposit rates \\
\hline & Spread between highest and lowest interbank rate \\
\hline & Customer deposits to total (non-interbank) loans \\
\hline & Foreign currency-denominated loans to total loans \\
\hline & Foreign currency-denominated liabilities to total liabilities \\
\hline & Net open position in equities to capital \\
\hline \multirow[t]{2}{*}{ Other financial corporations } & Assets to total financial system assets \\
\hline & Assets to GDP \\
\hline \multirow[t]{4}{*}{ Nonfinancial corporate sector } & Total debt to equity \\
\hline & Return on equity \\
\hline & Net foreign exchange exposures to equity \\
\hline & Number of applications for protection from creditors \\
\hline \multirow[t]{2}{*}{ Households } & Household debt to GDP \\
\hline & Household debt service and principal payments to income \\
\hline \multirow[t]{2}{*}{ Market liquidit } & Average bid-ask spread in the securities market \\
\hline & Average daily turnover ratio in the securities market \\
\hline \multirow[t]{3}{*}{ Real estate markets } & Real estate prices \\
\hline & Residential real estate loans to total loans \\
\hline & Commercial real estate loans to total loans \\
\hline
\end{tabular}

Table 2. Financial soundness indicators: BRD, Banca Transilvania

\begin{tabular}{|l|l|l|}
\hline \multicolumn{1}{|c|}{ Milioane RON } & \multicolumn{1}{|c|}{ BRD } & \multicolumn{1}{c|}{ TLV } \\
\hline Assets & 46346 & 19472 \\
\hline Loans & 33249 & 10871.5 \\
\hline Market share \% & $14.10 \%$ & $5.90 \%$ \\
\hline Solvability & 12.73 & 14 \\
\hline Overdue loans/Loans & $2,64 \%$ & $4,8 \%$ \\
\hline ROE & $19.50 \%$ & $27,5 \%$ \\
\hline Loans/bank deposit & $113.00 \%$ & $81.00 \%$ \\
\hline Profit & 779 & 610 \\
\hline
\end{tabular}

Source: www.brd.ro, www.bancatransilvania.ro, 2009, own calculations 
It is very important to analyze the main indicators of these major banks, and in case of slippages need a quick response from regulatory authorities, namely the NBR. Financial stability and banking sector stability, in particular, the sector which is one of the most vulnerable sectors in crisis, it is particularly important for the economic situation in a country. We presented from, the perspective of financial stability, the most important indicators of financial soundness, from the analysis we concluded that the Romanian banking system is stable, but there were some slippages, particularly in the loans outstanding. The most important causes affecting the volume of bad loans related to the fact that most loans were granted in foreign currency and because of the aggressive behavior of banks during the pre-crisis period, by increasing crediting levels at any price regardless of risk associated. Bank stability depends on the number of factors, most important are: ownership structure, market share growth rate of lending in previous periods, financing and refinancing ability of foreign markets / local or through international institutions.

\section{REFERENCES:}

[1]. Chant, J. (2003) Financial Stability as a Policy Goal, in Essays on Financial Stability, Technical Report No. 95, Bank of Canada, September

[2]. Crockett, A. (1997) Why is Financial Stability a Goal of Public Policy?, in Maintaining Financial Stability in a Global Economy, Symposium Proceedings, Federal Reserve Bank of Kansas City, August, pp. 55-96

[3]. Cerna, S. et all. (2008) Financial Stability, Editura Universitatii de Vest

[4]. De Haan, J.; Oosterloo, S. (2003) Transparency and accountability of central banks in their role of financial stability supervisor in OECD countries 2003, http://www.springer link.com/content/e275k711krhw2244/

[5]. Schinasi, G. (2004) Defining Financial Stability, IMF Working Paper No. WP/04/187, October

[6]. BNR (2009) Buletin lunar, iulie, www.bnro.ro

[7]. BNR (2006) Financial Stability Report, http://www.bnro.ro

[8]. International Monetary Fund (2009) The Financial stability report, www.imf.org

[9]. World Economic Outlook Database, October 2009, www.imf.org

[10]. Financial Soundness Indicators (FSIs) and the IMF, http://www.imf.org/external/np/sta/ fsi/eng/fsi.htm

[11]. Global Financial Stability Report: Navigating the Financial Challenges Ahead (Washington, October) , p.35, www.imf.org

[12].http://www.bnro.ro/Comitetul-National-pentru-Stabilitate-Financiara-3321.aspx, [Accessed 30 June 2010]

[13]. http://www.financialstabilityboard.org/about/mandate.htm ,[Accessed 30 June 2010]

[14]. www.bancatransilvania.ro, [Accessed 30 June 2010]

[15]. www.brd.ro, [Accessed 30 June 2010] 